\title{
MENGELOLA STRES DENGAN PENDEKATAN ISLAMI DAN PSIKOLOGIS
}

\author{
ANDI BUNYAMIN \\ Universitas Muslim Indonesia Makassar \\ Email: andi.bunyamin@umi.ac.id
}

\author{
(Article History) \\ Received May 01, 2021; Revised June 23, 2021; Accepted June 27, 2021
}

\begin{abstract}
Stress Management with Islamic and Psychological Approach
this article discusses stress management with an Islamic and psychological approach. Stress can be experienced by everyone regardless of socioeconomic background. If stress causes a person to suffer from both physical and mental disorders, such as nausea, diarrhea, anxiety, decreased memory, and fatigue, then this includes negative stress termed distress. Stress that causes an increase in achievement motivation and performance, resulting in innovation and creativity, is called positive stress named eustress. The stress that requires management is the one that has a negative impact (distress) for those who experience it so that it is not prolonged and has a more serious impact. Various approaches and strategies are offered by experts to manage stress such as physiological, psychological and religious approaches. This study offers two approaches in managing stress, namely: (1) Islamic approach through remembrance, prayer, reading the Qur'an, and (2) psychological approach, namely time management, relaxation, meditation. These approaches have been empirically tested and proven effective in reducing stress experienced by individuals or groups.
\end{abstract}

Keywords: Managing Stress, Islamic, Psychological

\begin{abstract}
Abstrak: Pengelolaan Stress Dengan Pendekatan Islami dan Psikologi
Artikel ini membahas tentang pengelolaan stres dengan pendekatan islami dan psikologis. Stres dapat dialami oleh setiap orang tanpa mengenal latar belakang sosial-ekonomi. Apabila stres itu menyebabkan seseorang menderita gangguan fisik maupun mental, seperti mual, diare, cemas, daya ingat menurun, dan kelelahan, hal tersebut termasuk stres negatif (negative stress) yang diistilahkan dengan distress. Stres yang menyebabkan peningkatan motivasi berprestasi dan kinerja, menghasilkan karya inovasi dan kreativitas, disebut stres positif (positive stress) yang diistilahkan dengan eustress. Adapun stres yang membutuhkan pengelolaan adalah stres yang memberi dampak negatif (distress) bagi yang mengalaminya agar tidak berkepanjangan dan berdampak lebih serius. Berbagai pendekatan dan strategi yang ditawarkan para ahli untuk mengelola stres, seperti pendekatan fisiologis, pendekatan psikologis, dan pendekatan religius. Kajian ini menawarkan dua pendekatan dalam mengelola stres, yaitu: (1) pendekatan Islami melalui zikir, do'a, membaca al-Qur'an; dan (2) pendekatan psikologis, yaitu manajemen waktu, relaksasi, meditasi. Pendekatan-pendekatan tersebut telah melalui uji empiris dan terbukti efektif menurunkan tekanan stres yang dialami oleh individu atau kelompok.
\end{abstract}

Kata kunci: Mengelola Stres, Islami, Psikologis 


\section{PENDAHULUAN}

enyebaran Covid-19 di Indonesia masih relatif tinggi, meskipun di daerah tertentu penyebarannya sudah melandai dan ada yang sudah masuk kategori zona hijau. Masyarakat diharapkan untuk beraktivitas di rumah termasuk beribadah yang diistilahkan dengan Work From Home (WFH) dengan menerapkan protokol kesehatan secara ketat sebagai salah satu ikhtiar untuk melindungi masyarakat agar tidak terinfeksi virus Covid-19 yang membahayakan kesehatan dan jiwa manusia.

Masyarakat diharapkan untuk bekerja, belajar dan beribadah dari rumah menimbulkan dampak positif dan negatif. Muslim (2020) menguraikan dampak positif yang terjadi karena WFH dan social distancing, di antaranya adalah masyarakat lebih memerhatikan kesehatan, hubungan keluarga yang semakin dekat, munculnya aktivitas-aktivitas baru yang produktif dan hemat, meningkatnya literasi pemanfaatan teknologi informasi, dan lainnya. Adapun dampak negatif yang sangat dirasakan oleh masyarakat, di antaranya adalah terbatasnya aktivitas, berkurangnya perputaran ekonomi masyarakat, model belajar dengan menggunakan online menimbulkan kebosanan dan kejenuhan karena kurang efektifnya interaksi, dan sebagainya.

Kejenuhan dan rasa bosan yang terus dirasakan dapat menjadi salah satu variabel yang dapat menyebabkan stres bagi seseorang, termasuk mahasiswa. Stres menjadi fenomena gunung es, banyak kasus yang tidak terlaporkan dan berisiko makin banyaknya orang yang mengalami stres dengan segala dampak buruk yang ditimbulkannya. Pertumbuhan ekonomi yang sangat rendah, lapangan kerja yang sangat terbatas, beban kerja yang tinggi, hubungan interpersonal yang kurang baik, dan kehidupan sosial yang cenderung individualistik akan menjadi stressor utama bila tidak dikelola dengan baik.

Masalah stres merupakan salah satu kajian utama dalam bidang kesehatan mental yang terus dikaji para peneliti dan ilmuwan. Stres merupakan krisis kesehatan yang berhubungan dengan beberapa penyakit, seperti penyakit kardiovaskular, kecemasan, dan depresi. Sebuah survei menemukan bahwa sekitar setengah dari orang Amerika pernah mengalami peristiwa stres besar. Banyak di antara mereka mengalami respon perilaku yang berhubungan dengan stres seperti kurang tidur, kehilangan nafsu makan, dan kurang bergairah untuk beraktivitas. Istilah stres pada umumnya mengacu pada stres negatif dalam percakapan seharihari (distress) (Li, et al., 2016).

Penelitian Cigna-360 Well-Being tahun 2019 menunjukkan bahwa tingkat stres masyarakat pada 23 negara, termasuk Indonesia, secara umum sebanyak 84\% dan stres di tempat kerja sebanyak 87\% dengan pemicu paling banyak diakibatkan karena masalah finansial (17\%), beban kerja (16\%), dan masalah kesehatan (14\%). Kementerian Kesehatan turut berupaya mengelola stres dengan dikeluarkannya Pedoman Kegiatan Keafiatan di Tempat Kerja (Wellness Program at 
Workplace) bersama dengan pengelolaan aktivitas fisik, gizi seimbang, dan upaya berhenti merokok di tempat kerja (KPKN, 2019).

Lumban Gaol (2016) dan Aryani (2016) memandang stres sebagai sesuatu yang pasti dialami oleh tiap orang. Banyak anak dan remaja mengalami stres belajar, tetapi tidak mengetahui cara mengelola stres yang tepat karena terbatasnya pengetahuan dan pengalaman mereka sehingga banyak yang gagal dalam studinya. Begitu pula orang dewasa, mereka lebih rentan mengalami stres yang tinggi dibanding anak-anak dan remaja diakibatkan oleh beban kerja, beban ekonomi, dan beban keluarga.

Sari (2018) menilai stres sebagai suatu keadaan yang membebani atau membahayakan kesejahteraan penderita yang dapat meliputi fisik, psikologis, sosial atau kombinasinya. Stres dapat menghasilkan berbagai respon. Beberapa hasil penelitian membuktikan bahwa respon-respon tersebut dapat berguna sebagai indikator terjadinya stres pada individu dan mengukur tingkat stres yang dialami individu. Strategi mengelola stres atau coping stress diperlukan sebagai faktor yang menentukan kemampuan manusia untuk melakukan penyesuaian terhadap situasi yang menekan (stressful life events).

Stres merupakan gejala umum yang dialami oleh masyarakat di seluruh belahan dunia, baik di negara miskin, berkembang, bahkan negara yang sudah maju perekonomian dan peradabannya. Tidak semua individu yang mengalami tekanan stres memiliki pengetahuan dan keterampilan untuk mengelola stres yang dialaminya sehingga dapat berdampak pada menurunnya kesehatan mental dan rasa bahagia mereka yang dapat menimbulkan gangguan psiko-somatik, yaitu penyakit fisik yang diakibatkan oleh gangguan psikologis. Oleh karena itu, sebuah strategi diperlukan untuk menangani secara cepat dan tepat gangguan stres tersebut, baik gejala maupun dampaknya. Kajian ini menawarkan dua pendekatan untuk mengelola stres, yaitu pendekatan islami dan pendekatan psikologis. Pemilihan dua pendekatan ini didasarkan pada pertimbangan bahwa kedua pendekatan tersebut memiliki hubungan fungsional antara satu dengan lainnya. Dalam pendekatan islami, berzikir, berdo'a, dan membaca al-Qur'an merupakan satu kesatuan yang tidak terpisahkan sehingga melakukan salah satu di antara tiga pendekatan itu dapat mencakup pendekatan lainnya. Pendekatan psikologis juga memiliki hubungan fungsional yang tinggi, seperti bila melakukan meditasi, prosesnya memiliki kesamaan dengan relaksasi. Begitu pula dalam pendekatan islami, bila dilakukan dapat merasakan dampak meditasi dan relaksasi.

\section{PEMBAHASAN}

\section{Pengertian Stres}

Kajian tentang "stres" pertama kali dilakukan oleh Hans Selye pada tahun 1950 dan dipandang sebagai tokoh utama dalam kajian stres. Selye mendefinisikan stres sebagai tanggapan nonspesifik tubuh terhadap tuntutan 
lingkungan, yang mengacu pada respons fisiologis, yang disebabkan oleh peristiwa stres (stressor) (Li, et al., 2016). Sejumlah faktor yang dapat menyebabkan stres, seperti trauma, ketegangan saraf, panas, dingin, kelelahan otot, udara yang tercemar, dan radiasi. Tubuh bereaksi terhadap stres dengan cara yang sama seperti bereaksi terhadap bahaya melalui serangkaian perubahan biokimia yang disebut sebagai Sindrom Adaptasi Umum.

Stres pada dasarnya merupakan konsep yang "netral" dan merujuk pada halhal yang sering dialami dan dirasakan manusia dalam kesehariannya. Stres adalah bahagian dari kehidupan manusia, setiap orang pernah dan akan mengalami gangguan stres, baik yang berskala ringan, sedang, maupun yang berat. Baqutayan (2015) menilai bahwa stres adalah bahagian yang tak terpisahkan dari peradaban moderen yang tidak bisa dihindari, baik dalam lingkungan keluarga, lingkungan sekolah, maupun lingkungan masyarakat yang dapat dialami oleh seluruh lapisan masyarakat tanpa mengenal umur, jenis kelamin, dan status sosial-ekonomi.

Banyak pengertian stres yang dikemukakan oleh ahli sesuai dengan sudut pandang mereka. Menurut Smith dan Lutgendorf, stres secara spesifik dapat diartikan sebagai respon fisik otomatis terhadap tantangan atau situasi lain yang mengharuskan seseorang untuk beradaptasi dengan perubahan (KPKN, 2019) Stres kerja merupakan suatu kondisi yang dirasakan karyawan karena beban kerja yang berlebihan, waktu yang sedikit, perasaan susah, dan ketegangan emosional yang menghambat performance karyawan tersebut (Robbins \& TJudge, 2011).

Vermunt mendefinisikan stres sebagai ketidaksesuaian antara tuntutan lingkungan (stressor) dengan kemampuan seseorang untuk memenuhi tuntutan tersebut. Khan menyatakan bahwa stres terjadi ketika seseorang menghadapi situasi yang dianggap sangat menekan dan tidak mampu dikelola atau melakukan adaptasi dengan baik sehingga menyebabkan terjadinya gangguan pada kesehatan fisik maupun mental. Hal ini sesuai pandangan Lazarus dan Folkman mengatakan bahwa keadaan stres yang dialami seseorang akan menimbulkan efek yang kurang menguntungkan, baik secara fisiologis maupun psikologis (Maryam, 2017).

Pada umumnya, orang yang mengalami distress tidak memiliki keterampilan dalam mengelola stres sehingga berdampak negatif bagi dirinya. apabila gagal dalam memilih strategi coping yang tepat, stres dapat menimbulkan dampak negatif bagi seseorang, seperti masalah kesehatan fisik akibat terjadinya gangguan psikologis yang disebut psiko-somatik atau hilangnya kebahagiaan individu. Oleh karena itu, sangat penting untuk memahami gejala-gejala awal stres dan segera dikelola dengan benar agar tidak menimbulkan dampak negatif yang berkelanjutan.

\section{Jenis-Jenis Stres}

Fakta menunjukkan bahwa banyak orang menilai stress itu selalu berkonotasi negatif dan menimbulkan gangguan pada kesehatan fisik dan psikis. Stres tidak selamanya berdampak buruk meskipun biasa dipersepsikan sebagai sesuatu yang negatif. Stres akan menjadi positif apabila memberi peluang untuk berhasil. Banyak 
ahli menilai bahwa stres yang mengandung tantangan bagi pekerja tidak sama dengan stres penghalang dalam pencapaian suatu tujuan. Gaol (2016) mengibaratkan stres sebagai dua sisi mata uang, yaitu dapat memberi pengaruh baik yang disebut dengan eustress atau sebaliknya memberi pengaruh negatif yang disebut dengan distress.

\section{Distress (Negative Stress)}

Sivasubramanian (2016) menilai bahwa setiap orang membutuhkan tekanan dan tantangan yang seimbang dalam hidup mereka untuk menimbulkan motivasi berprestasi atau motivasi kerja yang dapat meningkatkan prestasi dan produktivitas kerja. Akan tetapi, apabila suatu tantangan melebihi batas toleransi dan tidak dapat dikelola dengan tepat akan menimbulkan kecemasan sehingga tantangan yang diharapkan sebagai suatu yang dapat menimbulkan motivasi berubah menjadi sesuatu yang menggangu, hal inilah yang dikenal sebagai stres negatif (distress).

Distress adalah jenis stres yang mengancam dan berbahaya bagi diri seseorang yang mengalami tekanan tersebut, seperti tuntutan tugas akademik yang berlebihan, tuntutan kerja di luar batas kemampuan individu untuk menyelesaikannya atau suatu tuntutan yang tidak disenangi yang menguras energi yang berakibat pada menurunkan motivasi dan imunitas individu sehingga rentan mengalami gangguan kesehatan baik fisik maupun mental. Keadaan seperti inilah yang selama ini disebut oleh sebagian besar masyarakat sebagai stres dan inilah yang akan menjadi fokus pembahasan kita tentang manajemen stres.

\section{Eustress (Good Stres)}

Eustress berbeda dengan distress yang mengancam kesejahteraan dan keselamatan diri. Eustress memberi dampak positif bagi individu yang mengalaminya. Eustress adalah hasil dari respon terhadap stres yang bersifat baik, positif, dan konstruktif dapat meningkatkan motivasi bagi individu yang mengalaminya. Pelajar atau mahasiswa yang memiliki respon positif terhadap tekanan (stres) yang dialami, seperti tugas perkuliahan yang harus diselesaikan dalam waktu yang singkat dapat meningkatkan motivasi untuk belajar lebih giat dan menyelesaikan tugas dengan baik karena tidak ingin memperoleh nilai yang rendah yang dapat menurunkan harga diri dihadapan teman-temannya atau tidak ingin mengecewakan orang tua yang membiayainya. Pekerja yang memiliki respon positif terhadap tekanan dapat mendorong mereka untuk bekerja secara efektif dan efisien, menyelesaikan pekerjaan sebelum batas waktu yang diberikan, dan bahkan dapat berinovasi sehingga melahirkan karya-karya kreatif.

Penelitian Schwabe dan Wolf menunjukkan bahwa stres dapat menyebabkan berfungsinya beberapa sistem memori pada otak manusia. Penelitian tersebut membuktikan bahwa setelah seseorang mengalami stres, sistem berbasis corpus striatum (pusat saraf yang berada di dalam otak hemisphere dekat thalamus) dapat menggeser sistem berbasis hippocampus (bagian sistem limbik yang 
bertugas sebagai penyimpan memori) untuk membantu kinerja tugas-tugas yang ada di dalam otak. Dengan demikian, kemampuan sistem yang ada dalam otak bisa bekerja secara optimal dengan adanya stres yang diterima (Lumban Gaol, 2016: 8).

Stres sebagai sesuatu yang ada di sekitar manusia dan setiap saat dapat "menyerang" siapa saja. Perlu dipahami gejala-gejalanya agar dapat dikelola dengan cepat dan tepat sehingga dapat menjadi stress positif (eustress) yang mendorong seseorang untuk bekerja lebih kreatif dan produktif untuk melahirkan karya-karya inovatif, dan bagi pelajar atau mahasiswa akan meningkatkan motivasi berprestasi sehingga mampu menyelesaikan studi secara efektif dengan indeks prestasi yang tinggi.

\section{Gejala-Gejala Stres}

Rice menyimpulkan hasil kajian beberapa ahli bahwa ada tiga gejala dari stres kerja pada individu, yaitu gejala psikologis, fisiologis, dan gejala perilaku (Waluyo, 2019).

Gejala-gejala psikologis yang sering ditemui pada hasil penelitian mengenai stress, yaitu: (1) kecemasan, ketegangan, kebingungan dan mudah tersinggung; (2) perasaan kecewa, rasa marah, dan dendam (kebencian); (3) sensitif dan hiperaktif; (4) memendam perasaan, penarikan diri, dan depresi; (5) komunikasi yang tidak efektif; (6) perasaan terkucilkan dan terasing; (7) kebosanan dan ketidakpuasan kerja; (8) kelelahan mental; (9) penurunan fungsi intelektual, dan kehilangan konsentrasi; (10) kehilangan spontanitas dan kreativitas; serta (11) menurunnya rasa percaya diri (Waluyo, 2019).

Gejala-gejala fisiologis yang utama dari stress, di antaranya adalah: (1) meningkatnya denyut jantung, tekanan darah, dan kecenderungan mengalami penyakit cardiovascular; (2) meningkatnya sekresi dari hormon stress (contoh : adrenalin dan nonadrenalin); (3) gangguan gastrointestinal (misalnya gangguan lambung); (4) meningkatnya frekuensi dari luka fisik dan kecelakaan; (5) kelelahan secara fisik dan kemungkinan mengalami sindrom kelelahan yang kronis (chronic fatigue syndrome); (6) gangguan pernapasan, termasuk gangguan dari kondisi yang ada. g. gangguan pada kulit; (7) sakit kepala, sakit pada punggung bagian bawah, ketegangan otot; (8) gangguan tidur; dan (9) rusaknya fungsi imun tubuh, termasuk risiko tinggi kemungkinan terkena kanker (Waluyo, 2019).

Gejala-gejala perilaku yang utama dari stress, di antaranya adalah: (1) menunda, menghindari pekerjaan, dan absen dari pekerjaan; (2) menurunnya prestasi (performance) dan produktivitas; (3) meningkatnya penggunaan minuman keras dan obat-obatan; (4) perilaku sabotase dalam pekerjaan; (5) perilaku makan yang tidak normal (kebanyakan) sebagai pelampiasan, mengarah ke obesitas; (6) perilaku makan yang tidak normal (kekurangan) sebagai bentuk penarikan diri dan kehilangan berat badan secara tiba-tiba, kemungkinan berkombinasi dengan tanda-tanda depresi; (7) meningkatnya kecenderungan berperilaku beresiko tinggi, 
seperti menyetir dengan tidak hati-hati dan berjudi; (8) meningkatnya agresivitas, vandalisme, dan kriminalitas; (9) menurunnya kualitas hubungan interpersonal dengan keluarga dan teman; serta (10) kecenderungan untuk melakukan bunuh diri (Waluyo, 2019).

Ketiga Gejala umum stres dapat dirasakan secara berbeda oleh seseorang yang stres, ada yang merasakan banyak gejala dan ada juga merasakan sedikit gejala. Gejala yang dirasakan tergantung dari persepsi dan respon individu terhadap suatu stressor serta kemampuan seseorang mengelola stressor tersebut. Oleh karena itu, perlu dilakukan penanganan secara baik dengan memilih strategi cooping yang tepat untuk menghindari terjadinya dampak yang lebih buruk bagi individu.

\section{Teknik Mengelola Stress}

Seseorang yang mengalami stres negatif (distress) harus mampu mengelola stres tersebut agar tidak menimbulkan dampak negatif yang dapat memengaruhi kinerja dan kesehatan (fisik dan mental). Menurut Selye (1952), stres dapat menyebabkan gangguan yang membahayakan hidup seseorang kecuali jika memiliki respon adaptif yang memadai. Kemampuan beradaptasi, berfungsi dan aktifnya elemen-elemen jiwa dalam diri merupakan syarat utama untuk tetap bertahan hidup bersama stres. Dalam kajian ini, terdapat dua pendekatan umum untuk mengelola stres, yaitu pendekatan islami dan pendekatan psikologis dengan beberapa subbagian masing-masing pendekatan.

\section{Pendekatan Islami}

Saat ini terdapat kecenderungan adanya peningkatan kajian-kajian keagamaan di tengah masyarakat muslim, baik dari kelompok orang-orang terpelajar maupun masyarakat umum. Dampak dari meningkatnya kajian-kajian keagamaan tersebut terjadi peningkatan kesadaran dalam pengamalan ajaran agama. Hal ini dapat diamati dari meningkatnya animo masyarakat mengikuti salat berjamaah, terbentuknya kelompok-kelompok kajian Islam seperti majelis taklim, dan kelompok-kelompok zikir yang secara periodik melakukan taklim, berzikir dan tadarrus al-Qur'an secara berjamaah.

Secara normatif, seorang muslim yang mengamalkan ajaran agama Islam dengan baik dan istiqamah (wajib dan sunah) akan memiliki ketenangan jiwa tinggi dan tidak rentan dengan stres karena seluruh ajaran Islam memiliki dampak terhadap peningkatan kesehatan jiwa bagi yang mengamalkannya. Akan tetapi, tidak semua orang Islam memiliki pemahaman dan pengamalan yang baik terhadap ajaran Islam. Oleh karena itu, pada kajian ini dibahas tiga pengamalan dalam Islam yang dapat dijadikan strategi mengelola stres, yaitu zikir, do'a, dan membaca al-Qur'an.

\section{Zikir}

Praktek zikir bukan hal yang asing bagi orang muslim. Sejak zaman Nabi Muhammad saw. sampai sekarang, zikir telah dilaksanakan oleh orang Islam yang 
ingin menyucikan hati, menentramkan jiwa, dan mendekatkan diri kepada Allah swt. Zikir diucapkan dalam hati maupun dijaharkan, baik dilakukan secara pribadi maupun berkelompok. Banyak manfaat yang dapat diperoleh bagi orang yang berzikir. Selain memperoleh pahala yang besar dari Allah swt., orang yang berzikir juga dapat manfaat fungsional dalam bentuk ketenangan jiwa, sebagaimana firman Allah swt. dalam QS al-Ra‘d/13: 28.

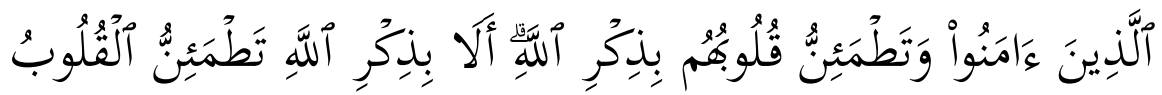

(Yaitu) Orang-orang yang beriman dan hati mereka menjadi tenteram dengan mengingat Allah. Ingatlah hanya dengan mengingat Allah-lah hati menjadi tenteram (Al-Qur'an dan Terjemahnya, n.d.)

Menurut Najati (2005), pengertian zikir secara bahasa adalah mengingat, sedangkan secara istilah yaitu ikhtiar sungguh-sungguh untuk mengalihkan gagasan, pikiran, dan perhatian manusia menuju Tuhan dan akhirat. Zikir ini bertujuan untuk membalikkan keseluruhan karakter manusia dan mengalihkan perhatian utama seseorang dari dunia yang sudah sangat dicintai menuju akhirat yang sejauh ini belum dikenali sama sekali (Ilyas, 2017).

Ketekunan seorang mukmin berzikir menyebut nama Allah swt. dengan bertasbih, bertakbir, beristigfar, berdo'a, dan membaca al-Qur'an akan mengantar pada kesucian jiwanya dan akan merasakan ketenangan (Najati, 2005). Ketenangan jiwa yang diperoleh para pengamal zikir akan menghambat kerja jaringan saraf simpatetis dan menstimulasi peningkatan kerja sistem saraf parasimpatetis, yaitu saraf yang mengeluarkan cairan-cairan "endorfin" yang menstimulasi terjadinya kedamaian dan ketenangan jiwa.

Beberapa penelitian ilmiah telah menemukan efek intensitas pengamalan zikir dan do'a terhadap penurunan kecemasan, peningkatan imunitas tubuh, dan ketenangan jiwa. Fatemi (Yurisaldi, 2010) menemukan berbagai teknik pengurangan stres yang dilakukan oleh mahasiswa keperawatan di Iran, di antaranya strategi dukungan sosial, menjaga persahabatan atau mencari teman baru, strategi humor, dan strategi spiritual zikir dan doa.

Aspek zikir yang dapat menyebabkan ketenangan bagi yang mengamalkannya adalah perasaan selalu bersama dan dalam pengawasan Allah swt. Yurisaldi (2010) menemukan bahwa kalimat yang mengandung huruf jahr, seperti kalimat "tauhid" laa ilaaha illallah dan "istighfar" astagfirullah dapat memperlancar pembuangan karbondioksida yang ada dalam paru-paru.

Hasil riset tentang manfaat zikir dapat menjadi pendorong bagi umat Islam untuk melakukan zikir secara rutin untuk meningkatkan kesehatan mental. Zikir adalah ibadah yang ringan karena dapat dilaksanakan pada semua kondisi, tidak membutuhkan biaya, dapat dilaksanakan kapan dan di mana saja (di rumah, di tempat kerja, dan masjid). Zikir memiliki keutamaan yang tinggi dan pahala yang 
besar dari Allah swt. memiliki manfaat fungsional bagi manusia, yaitu dapat menstimulasi cairan endorfin yang ada dalam otak yang menyebabkan jiwa merasa tenang dan damai, serta dapat meningkatkan sistem imunitas tubuh yang berdampak pada peningkatan taraf kesehatan.

\section{Do'a}

Do'a juga sangat baik untuk menenteramkan jiwa yang mengalami tekanan. Bila seseorang berdo'a, ia menyadari atas segala kelemahan manusia, menyadari dirinya sebagai makhluk lemah yang memiliki keterbatasan. Orang yang berdo'a sangat sadar atas kebesaran dan kemahakuasaan Allah sebagai pencipta seluruh makhluk yang ada di atas bumi ini, kepada Allah pula tertuju seluruh pengharapan untuk memenuhi segala kebutuhan, dan menyelesaikan segala masalah yang dihadapi manusia. Dengan demikian, berdo'a akan memberi dampak ketenangan karena seluruh hidup telah dipasrahkan kepada Allah swt. untuk memberikan yang terbaik menurut penilaian Allah. Banyak bukti empiris yang menunjukkan peran do'a dalam menenteramkan jiwa dan membantu mempercepat kesembuhan penyakit fisik.

Bartkowski, dkk., mengkaji beberapa hasil riset yang menunjukkan bahwa doa yang dilakukan secara berjamaah dan dilakukan dengan tertib dan khusyuk sangat efektif dalam mencegah depresi dan kecemasan, baik dalam jangka waktu singkat maupun dalam jangka waktu lama. Shihab (2006) mengisahkan pengalaman Alexis Carrel, seorang dokter spesialis bedah yang pernah mendapat hadiah Nobel dalam bidang kedokteran, dia menuturkan bahwa, "Banyak pasien yang ditangani mengalami percepatan kesembuhannya disebabkan karena banyak berdoa". Hasil survei majalah Times dan CNN pada tahun 1996 yang menunjukkan bahwa terdapat $70 \%$ pasien meyakini bahwa keimanan kepada Tuhan dan rajin berdo'a dapat mempercepat proses kesembuhan penyakit pasien dan terdapat $64 \%$ pasien menginginkan agar dokter memberi terapi psikoreligius do'a selain terapi medis (Hawari, 2005).

Do'a merupakan hal yang sangat penting bagi orang yang beriman sebagai bentuk persaksian kelemahan manusia dan pernyataan akan kebesaran Allah swt. Islam mengajarkan bahwa seluruh aktivitas manusia selalu disertasi dengan do'a sejak bangun tidur pada pagi hari sampai akan tidur kembali pada malam hari. Orang muslim yang senantiasa berdo'a akan selalu berpikir positif karena seluruh permasalahan hidupnya sudah disampaikan kepada Allah sebagai penguasa seluruh makhluk dan hal-hal yang mereka hadapi dipandang sebagai sesuatu yang terbaik, yang sudah diskenariokan oleh Allah kepadanya.

\section{Membaca Al-Qur'an}

Al-Qur'an adalah mukjizat terbesar yang diberikan Allah kepada Nabi Muhammad saw. menjadi ibadah bagi yang membacanya dan dapat menjadi 
penawar bagi orang-orang yang memiliki masalah kejiwaan. Allah swt. berfirman dalam QS Fușșilat/41: 44.

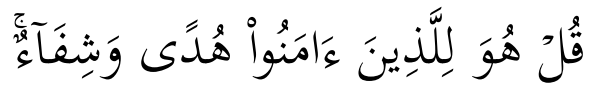

Katakanlah Al-Quran itu adalah petunjuk dan penawar bagi orang-orang yang beriman (Al-Qur'an dan Terjemahnya, n.d.).

Membaca al-Qur'an dengan tartil selain sebagai ibadah, juga dapat menjadi penawar jiwa bagi orang-orang yang hatinya tidak tenang, meskipun tidak memahami artinya. Namun demikian, bila ingin memperoleh manfaat yang lebih besar, seseorang diharapkan bukan sekadar membaca huruf demi huruf, tetapi memahami, merenungi arti dan makna suatu ayat. Menurut Hayyi (2012) bahwa tadabbur al-Qur'an adalah perenungan yang mendalam untuk memahami maksud dan makna dari suatu ayat atau surat dalam al-Qur'an. Dengan demikian, tadabbur al-Qur'an berarti memikirkan dan memerhatikan ayat-ayat al-Qur'an agar dapat memahami makna, hikmah, dan tujuannya untuk dijadikan sebagai pembelajaran.

Penelitian Ansyah, et al., (2019) menemukan bahwa pelatihan tadabbur surat al-Insyirah mampu menurunkan tingkat stres akademik pada mahasiswa. Hal ini berarti bahwa penghayatan terhadap al-Qur'an, dalam hal ini adalah QS al-Insyirah bisa digunakan sebagai pendekatan dalam psikoterapi terhadap gangguan psikologi. Meskipun penelitian ini dibatasi tadabbur pada surah al-Insyirah, membaca dan tadabbur pada ayat-ayat lain tetap dapat meningkatkan ketenangan dan menghilangkan gejala-gejala stres.

Al-Qur'an yang menjadi pedoman hidup bagi umat Islam telah dibuktikan oleh banyak penelitian tentang dampak fungsional bagi peningkatan kesehatan jiwa manusia. Oleh karena itu, membaca al-Qur'an harus menjadi gerakan umat Islam sekaligus mengkaji makna yang terkandung dalamnya. Untuk memperoleh dampak optimal dari membaca al-Qur'an, seseorang perlu memerhatikan etika dalam membaca al-Qur'an, memperhatikan tajwid, berusaha merenungi makna dari ayatayat tersebut, dan mengamalkan petunjuk-petunjuknya dalam kehidupan pribadi, keluarga, dan bermasyarakat.

\section{Pendekatan Psikologis}

Banyak cara yang ditawarkan para ahli untuk mengelola dan mengatasi stres agar tidak berdampak negatif pada individu yang mengalaminya. Sebelum memilih dan menentukan cara yang akan digunakan, seseorang memerlukan pemahaman yang baik tentang stres dengan segala aspeknya termasuk karakteristik individu yang mengalami stres agar dapat memilih strategi yang tepat dalam mengelola stres. Berikut ini akan diuraikan beberapa strategi yang bersifat psikologis untuk mengelola stres.

\section{Manajemen Waktu}


Waktu adalah salah satu sumber daya penting yang harus dikelola dengan baik agar pekerjaan yang dilakukan dapat selesai sesuai waktu yang telah ditetapkan. Pekerjaan yang tidak dapat diselesaikan sesuai rencana waktu yang ditetapkan dapat menjadi sumber stressor bagi pekerja yang dapat menyebabkan kecemasan atau depresi yang berakibat pada menurunnya produktivitas kerja bahkan menimbulkan dampak negatif berupa gangguan fisik. Oleh karena itu, dibutuhkan keterampilan manajemen waktu agar pekerjaan yang dilakukan dapat efektif dan efisien.

Ika Sandra (2012) mengartikan manajemen waktu sebagai kemampuan merencanakan, mengorganisasikan, memperketat jadwal, mengontrol penggunaan waktu, membuat prioritas, dan pelaksanaan suatu tanggung jawab individu demi pencapaian tujuan yang ditetapkan. Tujuan manajemen waktu untuk meningkatkan efektivitas dan efisiensi suatu pekerjaan. Efektivitas dapat dimaknai dengan pencapaian target tujuan dengan penggunaan waktu yang telah direncanakan, sedangkan efisien berarti menggunakan waktu kurang dari apa yang telah direncanakan sebelumnya.

Thomack (2012) menawarkan cara mengelola waktu dengan menetapkan tujuan, mengembangkan rencana, dan mengukur tingkat pencapaiannya. Dengan menetapkan tujuan, prioritas pekerjaan dapat disusun dengan mengklasifikasi pekerjaan sesuai dengan tingkat kepentingan dan jumlah waktu yang dibutuhkan untuk menyelesaikannya.

Pelajar atau pekerja yang mampu mengelola waktu dengan menetapkan tujuan, menyusun prioritas, mengevaluasi proses dan hasil dari apa yang dilakukan akan membantu menyelesaikan tugas dan pekerjaan yang telah direncanakan secara efektif dan efisien sehingga dapat terhindar dari deadline waktu yang sering menyebabkan seseorang bekerja dalam tekanan sehingga tidak mencapai hasil yang baik bahkan gagal menyelesaikan tugas.

\section{Relaksasi}

Relaksasi dewasa ini menjadi salah satu alternatif pendekatan psikologis yang banyak digunakan dalam mengelola stres dan kecemasan, baik sebagai terapi tersendiri atau bagian dari suatu terapi yang bersifat holistik. Manzoni, et al., (2008) mengemukakan bahwa praktek relaksasi yang dilakukan orang bervariasi, tetapi memiliki tujuan yang sama, yaitu menghasilkan dampak untuk menghilangkan gejala stres yang ditandai dengan melambatnya pernafasan, menurunnya tensi darah, konsumsi oksigen berkurang, dan munculnya ketenangan jiwa.

Relaksasi adalah pemusatan pikiran (konsentrasi) agar otot menjadi rileks. Dalam kondisi rileks, pembuluh darah menjadi elastis sehingga dapat memperlancar aliran darah ke seluruh tubuh yang menyebabkan perasaan menjadi rileks dan hangat, denyut jantung akan melambat dan kerja jantung tidak berat 
yang akan memengaruhi kerja organ-organ tubuh yang lain. Relaksasi juga dapat dimaknai sebagai meditasi penenangan dengan nafas yang dikonsentrasikan untuk mengembalikan keadaan tubuh menjadi bugar.

Penelitian Gangadharan dan Madani (2018) terhadap mahasiswa keperawatan di Universitas King Khalid Saudi Arabia menunjukkan bahwa relaksasi otot progresif sangat efektif dalam mengurangi tingkat depresi, kecemasan, dan stres mahasiswa keperawatan. Setelah intervensi sebagian besar peserta merasa rileks, keadaan emosi negatif menjadi normal kembali sehingga dapat beraktivitas belajar dalam keadaan tidak tertekan lagi.

Menurut Aryani (2016), manfaat nyata dari latihan relaksasi, di antaranya ialah: (1) relaksasi akan membuat individu lebih mampu menghindari reaksi yang berlebihan karena adanya stres; (2) masalah-masalah yang berhubungan dengan stres seperti hipertensi, sakit kepala, dan insomnia dapat dikurangi atau diobati dengan relaksasi; (3) mengurangi tingkat kecemasan, beberapa bukti telah menunjukkan bahwa individu dengan tingkat kecemasan yang tinggi dapat menunjukkan efek fisiologis positif melalui latihan relaksasi; (4) mengurangi kemungkinan gangguan yang berhubungan dengan stres dan mengontrol anticipatory anxiety sebelum situasi yang menimbulkan kecemasan, seperti ketika akan menghadapi ujian; (5) mengurangi perilaku tertentu yang sering terjadi selama periode stres seperti mengurangi jumlah rokok yang dihisap, konsumsi alkohol, pemakaian obat-obatan, dan makan yang berlebihan; (6) meningkatkan semangat dalam melakukan aktivitas sehari-hari; dan (7) kelelahan, aktivitas mental, dan atau latihan fisik yang tertunda dapat diatasi lebih cepat dengan menggunakan latihan.

\section{Meditasi}

Meditasi adalah kegiatan memusatkan pikiran kepada satu sasaran tertentu dengan tingkat kesadaran optimal dan merasakan efek meditasi tersebut dalam dirinya. Apabila seseorang tidak menyadari proses meditasinya atau dilakukan dalam keadaan tidak sadar, hal itu hanya disebut pemusatan perhatian saja (Suryani, 2000). Efek dari meditasi adalah terjadinya penurunan frekuensi gelombang otak, nafas menjadi lambat, dan kebutuhan oksigen semakin berkurang. Frekuensi gelombang otak mencapai keadaan alpha, keadaan ini dinamakan keadaan homeostatis atau seimbang. Dengan keadaan ketenangan otak seperti ini, otak akan mengeluarkan hormon endorfin yang berfungsi mengurangi rasa sakit dan menstimulasi ketenangan dan kedamaian dalam diri dan terjadilah self-healing.

Meditasi sering digunakan oleh terapis untuk menangani gangguan psikologis klien, baik digunakan secara tersendiri ataupun dikomplementasi dengan strategi lainnya. Tujuan meditasi menurut Widodo dan Purwanigsih (2018) untuk membiasakan tubuh mengatur irama nafas dengan tepat sehingga mempercepat 
terjadinya konsentrasi dan penghayatan sehingga dapat mempercepat proses penyembuhan, menurunkan tingkat stres, dan meningkatkan taraf kesehatan

Penelitian Hussain dan Bhushan (2010) menyimpulkan bahwa teknik meditasi kesadaran efektif dalam mengurangi stres yang dirasakan oleh remaja. Sebagai teknik penyembuhan, meditasi kesadaran dapat diberikan kepada remaja secara teratur untuk mengurangi stres mereka dan guru juga dapat dilatih untuk menggunakan meditasi bagi siswanya. Hal ini sejalan dengan hasil penelitian Sari (2018) yang menemukan bahwa meditasi efektif menurunkan tingkat stres atau meningkatkan ambang stres individu sehingga membuatnya lebih toleran terhadap stres.

Meditasi pada awalnya adalah bagian dari praktek ibadah pemeluk agama Hindu dan Budha, tetapi meditasi telah mengalami modifikasi dan perkembangan karena telah dijadikan sebagai salah satu alternatif pemulihan kebugaran dan terapi bagi penderita gangguan psikologis. Dalam Islam, praktek do'a dan zikir secara khusyuk sebenarnya ekuivalen dengan praktek meditasi. Oleh karena itu, bagi orang muslim yang tidak terampil melaksanakan praktek meditasi, mereka cukup duduk berdiam diri penuh khusyuk kemudian berdo'a dan berzikir, insya Allah akan mendapatkan efek ketenangan sama dengan orang yang melaksanakan meditasi, bahkan lebih bermakna karena ada nilai-nilai llahiyah di dalamnya.

\section{PENUTUP/SIMPULAN}

Stres ada di sekitar manusia dan menjadi bagian yang tidak terpisahkan dari kehidupan yang dapat dialami oleh siapa saja dan kapan saja. Stres pada dasarnya bersifat netral tidak berdampak buruk bila yang mengalami mampu mengelola dan memiliki sistem imunitas yang tinggi terhadap stres. Stres pada dasarnya dikelompokkan ke dalam dua jenis, yaitu distress dan eustress. Apabila stres itu menyebabkan seseorang mengalami berbagai gangguan fisik maupun mental, seperti mual, diare, cemas, daya ingat menurun, dan kelelahan, hal-hal tersebut termasuk stres negatif (negative stress) yang diistilahkan dengan distress. Adapun stres yang menyebabkan peningkatan motivasi berprestasi dan bekerja, menghasilkan karya inovasi dan kreativitas, disebut stres positif (positive stress) yang diistilahkan dengan eustress. Stres negatif atau distress penting dikelola agar tidak menimbulkan dampak buruk bagi kesehatan dan mental seseorang.

Terdapat dua pendekatan utama yang dapat digunakan sebagai strategi mengelola stres, yaitu pendekatan Islam dan psikologis. Pendekatan Islam dilakukan dengan zikir, do'a, dan membaca al-Qur'an, sedangkan pendekatan psikologis dilakukan dengan cara mengelola waktu, relaksasi, dan meditasi. Berbagai temuan menunjukkan efektivitas pendekatan-pendekatan pengelolaan stres yang telah dikemukakan dapat menurunkan bahkan menghilangkan beban stres yang dialami seseorang. 


\section{DAFTAR PUSTAKA}

Al-Qur'an dan Terjemahnya. (n.d.). Al-Mujamma' al-Malik Fahd li Thabā'ah alMushhaf al-Syarif.

Ansyah, E. H., Muassamah, H., \& Hadi, C. (2019). Tadabbur Surat Al-Insyirah untuk Menurunkan Stres Akademik Mahasiswa. Jurnal Psikologi Islam Dan Budaya, 2(1), 9-18. https://doi.org/10.15575/jpib.v2i1.3949

Aryani, F. (2016). Stres Belajar: Suatu Pendekatan dan Intervensi Konseling. Makassar: Edukasi Mitra Grafika.

Gangadharan, P., \& Madani, A. H. (2018). Effectiveness of Progressive Muscle Relaxation Techniques on Depression, Anxiety and Stress among Undergraduate Nursing Students. International Journal Of Health Sciences and Reserch, 8(2), 155-163.

Hawari, D. (2005). Al-Qur'an: Ilmu Kedokteran Jiwa dan Kesehatan Jiwa. Jakarta: Dana Bhaktin Prima Yasa.

Hayyi, A. (2012). Fiqh al-Islam wa Adillatuh. Yogyakarta: Cakrawala.

Hussain, D., \& Bhushan, B. (2010). Psychology of meditation and health: Present status and future directions. International Journal of Psychology and Psychological Therapy, 10(3), 439-451.

Ika Sandra, K. (2012). Manajemen Waktu, Efikasi-Diri Dan Prokrastinasi. Persona: Jurnal Psikologi Indonesia. 2(3), 217-222. https://doi.org/10.30996/persona.v2i3.140

Ilyas, R. (2017). Zikir dan Ketenangan Jiwa: Telaah atas Pemikiran Al-Ghazali. Jurnal Dakwah Dan Pengembangan Sosial Dan Kemanusiaan, STAIN Syaikh Abdurrahman Siddik Bangka Belitung, 8(1), 90-106.

KPKN. (2019). Pedoman Strategis dan Langkah Aksi Pengeloaan Stres (Periode 20). Komite Penaggulangan Kanker Nasional.

Li, C.-T., Cao, J., \& Li, T. M. H. (2016). Eustress or distress. 1209-1217. https://doi.org/10.1145/2968219.2968309

Lumban Gaol, N. T. (2016). Teori Stres: Stimulus, Respons, dan Transaksional. Buletin Psikologi, 24(1). https://doi.org/10.22146/bpsi.11224

Manzoni, G. M., Pagnini, F., Castelnuovo, G., \& Molinari, E. (2008). Relaxation training for anxiety: A ten-years systematic review with meta-analysis. BMC Psychiatry, 8. https://doi.org/10.1186/1471-244X-8-41

Maryam, S. (2017). Strategi Coping: Teori Dan Sumberdayanya. JURKAM: Jurnal Konseling Andi Matappa, 1(2), 101. https://doi.org/10.31100/jurkam.v1i2.12 
Muslim, M. (2020). Moh . Muslim : Manajemen Stress pada Masa Pandemi Covid19 " 193. Jurnal Manajemen Bisnis, 23(2), 192-201.

Najati, M. U. (2005). Al-Qur'an dan Psikologi. Arah Pustaka.

Robbins, S. P. \& Judge, T. A. (2011). Perilaku Organisasi (12th ed.). Jakarta: Salemba Empat.

Baqutayan, S. M. (2015). Stress and Coping Mechanisms: A Historical Overview. Mediterranean Journal of Social Sciences, 6(2S1), 479-488. https://doi.org/10.5901/mjss.2015.v6n2s1p479.

Sari, N. P. W. P. (2018). Pengaruh Meditation Healing Exercise terhadap Tingkat Stres dan kualitas Hidup Lansia Penderita Penyakit Kronis: Hipertensi dan diabetes Mellitus. In Fakultas Keperawatan Universitas Katolik Widya Mandala Surabaya.

Selye, H. (1952). Allergy and the General Adaptation Syndrome. International Archives of Allergy and Immunology, 3(4), 267-278. https://doi.org/10.1159/000227975.

Shihab, M. Q. (2006). Wawasana al-Qur'an tentang Zikir dan Do'a. Jakarta: Lentera Hati.

Sivasubramanian. (2016). Eustress Vs Distress-A Review. International Journal of Research in Humanities \& Soc. Sciences, 4(5), 12-15.

Suryani, L. K. (2000). Menemukan Jati Diri dengan Meditasi. Jakarta: Elex Media Komputindo.

Thomack, B. (2012). Time Management for Today's Workplace Demands. Workplace Health \& Safety, 60(5), 201-203. https://doi.org/10.1177/216507991206000503.

Waluyo, M. (2019). Manajemen Psikologi Industri (Revisi). Jakarta: Literasi Nusantara.

Widodo, G. G., \& Purwanigsih, P. (2018). Menderita Hipertensi di Unit Rehabilitasi Sosial Wening Wardoyo Ungaran Kabupaten Semarang. 111-118.

Yurisaldi. (2010). Berdzikir untuk Kesehatan Saraf. Jakarta: Zaman. 